\title{
Effect of environmental factors on performance of purebred and crossbred Santa Inês lambs from birth to 154 days of age
}

\author{
Natália Albieri Koritiaki ${ }^{1}$, Edson Luis de Azambuja Ribeiro², Ivone Yurika Mizubuti², Leandro \\ das Dores Ferreira da Silva², Marco Aurélio Alves de Freitas Barbosa², Danielle Clivati Scerbo", \\ Carolina Amália de Souza Dantas Muniz², Francisco Fernandes Júnior ${ }^{1}$
}

\footnotetext{
${ }^{1}$ Programa de Pós-Graduação em Ciência Animal, UEL - Londrina, PR, Brazil.

${ }^{2}$ Departamento de Zootecnia, UEL - Londrina, PR, Brazil.
}

\begin{abstract}
The objectives of this study were to evaluate the environmental effects (age of dam at lambing, type of birth and sex of lamb) and genetic groups (Santa Inês and 1/2 Santa Inês) on weight and morphometric measurements (heart girth, body length and height) of lambs; to test linear and allometric regressions to predict the weight through the measurements; and to describe the type of growth of the measurements from weight. Weight and morphometric measurements were sampled from birth to 154 days of age, at every 14 days. For the evaluation of the environmental factors and to predict the regressions the data of birth, weaning and 154 days of age were used; and to determine the type of growth all the data collected were used. The lambs derived from younger (two-tooth) ewes recorded lower averages than the ones from eighttooth ewes for weight, heart girth and body length at birth and length at weaning. The animals born from single births presented higher average weight from birth to weaning, as well as of all the measurements from birth to 154 days of age than those from twin births. There was no difference between the genetic groups Santa Inês and $1 / 2$ Santa Inês. The correlations between the weight and measurements were significant, and it was possible to predict the weight from the morphometric measurements through regressions. The type of weight gain with heart girth was isometric, while with length it was positive allometric, and with height it was negative allometric. Thereby, in the absence of a scale it is possible to predict the weight from the morphometric measurements, and the type of birth is the most important factor that affects the development of lambs from birth to weaning.
\end{abstract}

Key Words: allometric growth, body morphometry, body weight, sheep

\section{Introduction}

Sheep-raising is becoming an important economic activity in Brazil, contributing to the availability of products such as meat, in addition to generating employment in rural and urban areas (Araújo Filho et al., 2007).

In the systems of sheep meat production it is necessary to pay special attention to the moment when the lambs are developing, because this is one of the major responsible factors for the success of the production. The earlier the animals develop, the faster they will reach the slaughtering conditions and, consequently, the cheaper will be the system (Mexia et al., 2004; Pacheco \& Quirino, 2008).

It is important to consider the various environmental factors, such as the year and the type of birth, the sex of the lamb and the age of the ewe at lambing, once they may affect the proper development of the lambs (Carneiro et al., 2007).

Even though most of the performance assessments of animals are only related to the weight, other measurements related to the body structure, such as body length, heart girth and height, are important (Menezes et al., 2008). According to Silva et al. (2006), it is possible to estimate the live weight and other body aspects related to productivity through the biometric measurements of the lambs.

The study of the type of growth explains part of the quantitative differences that are produced between the animals and represents an effective way to study the different body parts. It is based on the fact that the body development depends more on the weight than on the time required to reach it (Perez, 2002).

The objectives were to determine the influence of the type of birth, the sex of the offspring, the genetic group, the weight and the age of the ewe at lambing related to the weight and morphometric measurements of the lambs from birth to 154 days of age; to test linear and allometric regressions in order to predict the live weight through the body measurements; and finally, to describe the type of development of the body measurements within the studied period. 


\section{Material and Methods}

The data came from the sheep-raising sector of the Farm School of Universidade Estadual de Londrina (UEL), collected in 2009. The experimental unit is located at latitude and longitude of $23^{\circ} 23^{\prime} \mathrm{S}$ and $51^{\circ} 11^{\prime} \mathrm{W}$.

The evaluated ewes and lambs were kept on Coastcross (Cynodon dactylon (L.) Pers) pasture, with mineralized salt disposed in appropriate troughs, and received sorghum silage supplementation and concentrate during the winter periods. The sanitary management was the usual at the property, with worm control done according to fecal exam results. The lambs were weaned at 70 days of age and after the same period they were separated from their dams and kept in the same conditions previously described.

Thirty pure and eight crossbred ( $1 / 2$ Santa Inês $+1 / 2$ undefined breed) Santa Inês lambs were analyzed. For the general analysis of environmental effects and genetic groups the traits weight and body measurements were used, and for analysis of growth type (allometric or isometric) measurements obtained from birth to 154 days of age every 14 days were used, totaling 12 measurements per trait.

Morphometric measurements were obtained according to the methodology described by Costa Júnior et al. (2006), with the aid of a measuring tape, with the animal kept in the correct aplombs position. The height was measured between the highest point of the interscapular region (withers) and the ground. Body length was measured from the wither to the tail insertion. Heart girth was measured on the external circumference of the thoracic cavity, on the axillae.

The studied traits were subjected to an analysis of variance, having genetic group, type of birth (single or twin), sex (male or female) and age of the ewe at lambing (2, 4, 6, or 8 permanent incisors) as independent variables and weight of the ewe at lambing as covariable. The interactions between the independent variables were not considered in the final analysis as they did not present any significance $(\mathrm{P}>0.05)$. The averages of the age of the ewe at lambing were compared by the Tukey test, and the other ones by the F test (SAS - Statistical Analysis System, version 6.10). The linear model used in the analysis of the traits weight and morphometric measurements was:

$$
Y_{i j k l m}=\mu+I_{i}+S_{j}+G_{k}+T_{l}+P_{n}+\varepsilon_{i j k l m}
$$

where $Y_{i j k l m}=$ dependent variables (weights or body measurements); $\mu=$ overall mean; $I_{i}=$ effect of the age of the ewe at birth, where i $=2,4,6$ or 8 teeth; $S_{j}=$ effect of the sex of the lamb, where $\mathrm{j}=$ male or female; $G_{k}=$ effect of the genetic group, where $\mathrm{k}=$ Santa Inês or $1 / 2$ Santa Inês; $T_{l}=$ effect of the type of birth, where $1=$ single or twin; $P_{n}=$ effect of the weight of the ewe at lambing (covariable); and $\varepsilon_{i j k l m}=$ random error associated with each observation.

Linear and allometric regressions were tested to predict the live weight of the lambs from birth to 154 days of age from body measurements through the REG procedure of the computer system SAS (Statistical Analysis System, version 6.10). In the multiple linear regression equations, using more than one measure to predict the weight, the gradual elimination procedure REG stepwise of SAS (Statistical Analysis System, version 6.10) was used. The following models were used:

$$
\begin{aligned}
& -\mathrm{Y}=\mathrm{a}+\mathrm{bX} \text { (Linear) } \\
& -\mathrm{Y}=\mathrm{a}+\mathrm{b}_{1} \mathrm{X}_{1}+\ldots+\mathrm{b}_{\mathrm{n}} \mathrm{X}_{\mathrm{n}} \text { (Multiple linear) } \\
& -\mathrm{Y}=\mathrm{a} \mathrm{X}^{\mathrm{b}} \text { (Allometric) }
\end{aligned}
$$

where $\mathrm{Y}=$ live weight; $\mathrm{a}=$ intercept; $\mathrm{X}=$ body measurements; $b=$ regression coefficient of $Y$ on $X$; and $n=$ number of body measurements. The adhesion of the model was evaluated through the coefficient of determination $\left(\mathrm{R}^{2}\right)$ of the equations.

The Huxley (1932) equation " $\mathrm{Y}=\mathrm{aX}$ ", used to predict the weight and determine the type of growth, was analyzed through the logarithmic transformation into a simple linear regression: "ln $Y=\ln a+b(\ln X)$ ", in which " $Y$ " was considered the weight of the animal, " $X$ " the size of the body parts of the animal, "a" the logarithmic interception of the linear regression over " $Y$ " (antilogarithm of "a") and " $b$ " the relative growth coefficient, or the allometric coefficient, which is the relative growth speed of " $Y$ " relative to " $\mathrm{X}$ ".

The analysis to obtain the allometric coefficients was carried out on SAS (Statistical Analysis System, version 6.10). To test the hypothesis " $b=3.0$ " Student's t-test was carried out at $1 \%$ level of significance. In relations between traits of different unit measurements, if " $b=3.0$ ", the growth was termed isometric, indicating that the growth rates of " $X$ " and " $Y$ " were similar; if " $b \neq 3.0$ ", the growth was considered allometric, i.e., the growth of " $X$ " and "Y" were distinguished (Rocha et al., 2002).

\section{Results and Discussion}

Lambs born from two-tooth ewes, which are the youngest ones, presented the lowest average weight, heart girth and height at birth, while the lambs of older (eighttooth) ewes presented the highest averages for the same traits. For body length at weaning and average length gain from birth to weaning, the lambs born from intermediate age (four-tooth) ewes presented the highest averages (Table 1).

The lower averages at birth, of lambs born from young ewes still growing, are probably due to the lower development 
Table 1 - Weight, heart girth, length and height at birth, at weaning and at 154 days of age; and average daily gain for these traits from birth to weaning (B-W) from weaning to 154 days of age (W-154) and from birth to 154 days of age (B-154), according to the age of dam at lambing

\begin{tabular}{|c|c|c|c|c|}
\hline \multirow{2}{*}{ Traits } & \multicolumn{4}{|c|}{ Age of dam at lambing (teeth) } \\
\hline & Two-tooth & Four-tooth & Six-tooth & Eight-tooth \\
\hline Number of observations & 4 & 15 & 10 & 9 \\
\hline Weight at weaning, $\mathrm{kg}$ & $13.02 \pm 1.35$ & $14.62 \pm 0.77$ & $14.25 \pm 0.89$ & $12.55 \pm 0.97$ \\
\hline Weight at 154 days of age, $\mathrm{kg}$ & $15.30 \pm 2.53$ & $17.10 \pm 1.46$ & $16.12 \pm 1.67$ & $16.00 \pm 1.81$ \\
\hline Weight gain (B-W), kg/day & $0.14 \pm 0.01$ & $0.15 \pm 0.01$ & $0.14 \pm 0.01$ & $0.11 \pm 0.01$ \\
\hline Heart girth at birth, $\mathrm{cm}$ & $35.09 \pm 1.31 \mathrm{~b}$ & $36.27 \pm 0.75 b$ & $38.12 \pm 0.86 \mathrm{ab}$ & $39.20 \pm 0.94 \mathrm{a}$ \\
\hline Heart girth at weaning, $\mathrm{cm}$ & $53.03 \pm 1.80$ & $56.97 \pm 1.04$ & $56.73 \pm 1.19$ & $55.85 \pm 1.29$ \\
\hline Heart girth at 154 days of age, $\mathrm{cm}$ & $57.64 \pm 2.64$ & $62.05 \pm 1.52$ & $60.41 \pm 1.75$ & $59.96 \pm 1.90$ \\
\hline Heart girth gain (B-W), cm & $0.25 \pm 0.01$ & $0.29 \pm 0.01$ & $0.26 \pm 0.01$ & $0.23 \pm 0.02$ \\
\hline Heart girth gain (W-154), cm/day & $0.05 \pm 0.02$ & $0.06 \pm 0.01$ & $0.04 \pm 0.01$ & $0.04 \pm 0.01$ \\
\hline Heart girth gain (B-154), cm/day & $0.14 \pm 0.01$ & $0.16 \pm 0.01$ & $0.14 \pm 0.01$ & $0.13 \pm 0.01$ \\
\hline Length gain $(\mathrm{W}-154), \mathrm{cm} /$ day & $0.06 \pm 0.01$ & $0.04 \pm 0.01$ & $0.04 \pm 0.01$ & $0.04 \pm 0.01$ \\
\hline Length gain (B-154), cm/day & $0.13 \pm 0.01$ & $0.14 \pm 0.01$ & $0.13 \pm 0.01$ & $0.12 \pm 0.01$ \\
\hline Height at birth, $\mathrm{cm}$ & $36.06 \pm 0.86 b$ & $39.42 \pm 0.50 \mathrm{a}$ & $38.78 \pm 0.57 \mathrm{a}$ & $39.83 \pm 0.62 \mathrm{a}$ \\
\hline Height at weaning, $\mathrm{cm}$ & $54.04 \pm 1.58$ & $56.01 \pm 0.91$ & $54.68 \pm 1.05$ & $55.04 \pm 1.14$ \\
\hline Height at 154 days of age, $\mathrm{cm}$ & $57.01 \pm 1.98$ & $61.05 \pm 1.14$ & $58.62 \pm 1.3$ & $59.48 \pm 1.4$ \\
\hline Height gain (B-W), cm/day & $0.25 \pm 0.01$ & $0.23 \pm 0.01$ & $0.22 \pm 0.01$ & $0.21 \pm 0.01$ \\
\hline Height gain (W-154), cm/day & $0.03 \pm 0.01$ & $0.06 \pm 0.01$ & $0.04 \pm 0.01$ & $0.05 \pm 0.01$ \\
\hline Height gain (B-154), cm/day & $0.13 \pm 0.01$ & $0.14 \pm 0.01$ & $0.12 \pm 0.01$ & $0.12 \pm 0.01$ \\
\hline
\end{tabular}

Means followed by different letters in the row differ significantly $(\mathrm{P}<0.05)$.

of reproductive organs and low uterine irrigation of these ewes and the possible competition between the fetus and the ewe for nutrients (Souza et al., 2003).

Moura Filho et al. (2005) and Mohammadi et al. (2010) reported that younger ewes produce lighter lambs at weaning due to lower milk production. However, in this study there was no difference in the age of the ewe at lambing in the average weight at weaning and the average weight gain from birth to weaning (Table 1). A possible explanation for this fact is that the lambs had access to the supplemental feeding program of ewes, which might have partially compensated the growth of lambs born from younger ewes at pre-weaning.

Lamb weight and measurements evaluated during the post-weaning period were not influenced by the age of the ewe at lambing. According to Souza et al. (2003), in this period the animals are already independent in their feeding, depending more on their genetic potential to their growth than on the maternal effects.

Lambs born from single births presented higher averages than those born from twin births for all the evaluated traits from birth to weaning (Table 2). The average weight at birth and at weaning were $3.05 \pm 0.16 \mathrm{~kg}$ to $4.24 \pm 0.13 \mathrm{~kg}$ and $11.31 \pm 0.79 \mathrm{~kg}$ to $15.91 \pm 0.67 \mathrm{~kg}$, respectively, in which the lowest averages were of lambs born from twin births and the highest of lambs born from single births.

Several authors found influence of the type of birth on lamb performance, in which the ones born from single birth presented greater performance than the ones born from twin birth (Rashidi et al., 2008; Rocha et al., 2009; Mohammadi et al., 2010). The explanation for this fact is the nonexistence of intrauterine competition or competition for food (maternal milk) in single-birth lambs (Barros et al., 2005).

Lambs born from single birth presented higher averages than the ones born from twin birth at 154 days of age for all the body measurements, but the same did not happen with weight.

This absence of difference in weight at 154 days of age and the daily average weight gains until this age might suggest that the lambs born from twin birth presented a compensatory gain at post-weaning. This enhances the advantage of selecting ewes of twin birth from the flocks, aiming to increase production.

There was no difference $(\mathrm{P}>0.05)$ for the sex effect (Table 2), except for weight at birth, wherein males 
Table 2 - Weight, heart girth, length and height at birth, at weaning and at 154 days of age; and average daily gain for these traits from birth to weaning (B-W), from weaning to 154 days of age (W-154) and from birth to 154 days of age (B-154), according to the type of birth and sex of lamb

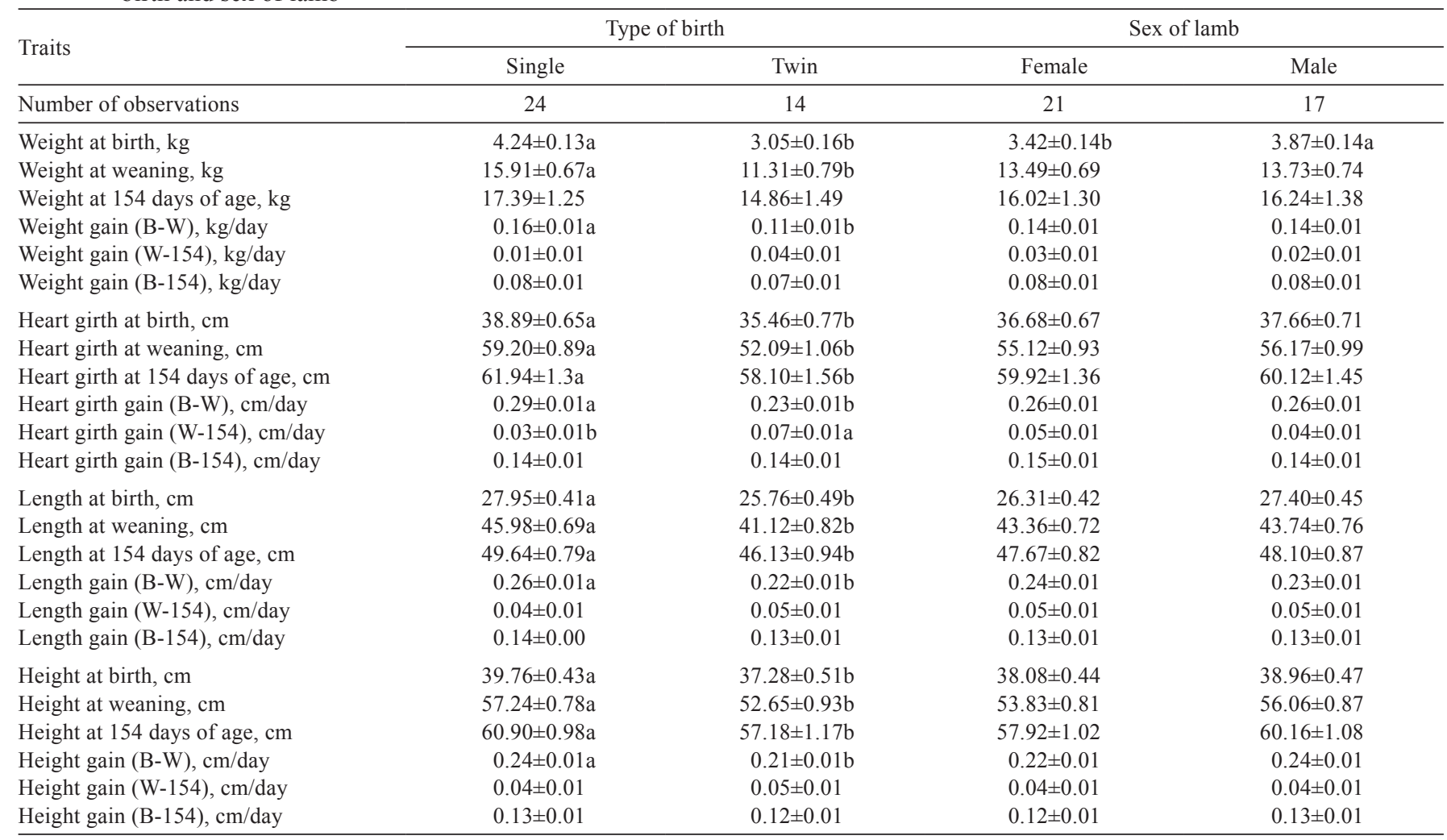

Means followed by different letters in the row differ significantly $(\mathrm{P}<0.05)$.

$(3.87 \pm 0.14 \mathrm{~kg})$ were heavier than females $(3.42 \pm 0.14 \mathrm{~kg})$. These results partially agree with the ones found by Moura Filho et al. (2005) and Rocha et al. (2009), which did not show significant differences between males and females from birth to weaning. The absence of difference can be due to the young age of the animals, in which the sexual hormones, responsible for the dimorphism between the sexes, are not as active as in older animals (Nunes, 2008).

Costa Júnior et al. (2006) found no differences between the sexes for weight and body measurements of lambs from birth to one year of age; however, they found difference in older animals. Therefore, they concluded that the differences due to sexual dimorphism increase as the animals age.

Purebred and crossbred $1 / 2$ Santa Inês did not present differences for the evaluated traits (Table 3). This result agrees with those obtained by Araújo Filho et al. (2007) and Rocha et al. (2009). Mexia et al. (2004) reported that during the pre-weaning period the growth is more related to the milk production of the dam and to the nutritional support than to the genotype of the offspring, so the lambs do not express the genotypic differences expected at this stage.

The covariable weight of the ewe at lambing exerted significant linear effect on body length at birth; on weight, heart girth, body length and height at weaning; and on body length and height at 154 days of age (Table 4). The weight of the ewe at birth is mostly related to its nutritional status during pregnancy. According to Pacheco \& Quirino (2008), when females are well nourished in the pre and postlambing periods they tend to produce lambs with better performance.

Fernandes et al. (2001) and Koritiaki et al. (2012) reported that the weight of the ewe at lambing (nutritional status) had a linear effect on the weight of the lambs from birth to weaning. Koritiaki et al. (2012) also found a linear effect on heart girth, length and body height at weaning. However, Silva \& Araújo (2000) found a linear effect of weight at lambing only on weight at birth, but they found a quadratic effect on weight from 56 to 112 days of age.

Correlations between body measurements and between the weights and measures were all significant $(\mathrm{P}<0.05)$ and positive (Table 5), agreeing with the results obtained by Sowand \& Sobola (2008) and Fajemilehin \& Salako (2008). The measurement which was most correlated to weight was heart girth; this occurred from birth to 154 days of age ( 0.74 at birth, 0.90 at weaning and 0.88 at 154 days of age). Because of the high correlations with body weight, 
Table 3 - Weight, heart girth, length and height at birth, at weaning and at 154 days of age; and average daily gain for these traits from birth to weaning (B-W), from weaning to 154 days of age (W-154) and from birth to 154 days of age (B-154), according to the genetic group

\begin{tabular}{|c|c|c|}
\hline \multirow{2}{*}{ Traits } & \multicolumn{2}{|c|}{ Genetic group } \\
\hline & Santa Inês & $1 / 2$ Santa Inês \\
\hline Number of observations & 30 & 8 \\
\hline Weight at birth, kg & $3.71 \pm 0.10$ & $3.58 \pm 0.18$ \\
\hline Weight at weaning, $\mathrm{kg}$ & $13.06 \pm 0.53$ & $14.17 \pm 0.91$ \\
\hline Weight at 154 days of age, $\mathrm{kg}$ & $16.10 \pm 1.00$ & $16.15 \pm 1.70$ \\
\hline Weight gain $(\mathrm{B}-\mathrm{W})-\mathrm{kg} /$ day & $0.13 \pm 0.01$ & $0.15 \pm 0.01$ \\
\hline Weight gain (W-154) - kg/day & $0.03 \pm 0.01$ & $0.02 \pm 0.01$ \\
\hline Weight gain (B-154) - kg/day & $0.08 \pm 0.01$ & $0.08 \pm 0.01$ \\
\hline Heart girth at birth, $\mathrm{cm}$ & $37.22 \pm 0.52$ & $37.12 \pm 0.88$ \\
\hline Heart girth at weaning, $\mathrm{cm}$ & $54.54 \pm 0.71$ & $56.75 \pm 1.22$ \\
\hline Heart girth at 154 days of age, $\mathrm{cm}$ & $59.47 \pm 1.05$ & $60.57 \pm 1.78$ \\
\hline Heart girth gain $(B-W), \mathrm{cm} /$ day & $0.24 \pm 0.01$ & $0.28 \pm 0.01$ \\
\hline Heart girth gain $(\mathrm{W}-154), \mathrm{cm} /$ day & $0.05 \pm 0.01$ & $0.04 \pm 0.01$ \\
\hline Heart girth gain (B-154), cm/day & $0.14 \pm 0.01$ & $0.15 \pm 0.01$ \\
\hline Length at birth, $\mathrm{cm}$ & $26.79 \pm 0.33$ & $26.93 \pm 0.56$ \\
\hline Length at weaning, $\mathrm{cm}$ & $42.59 \pm 0.55$ & $44.51 \pm 0.94$ \\
\hline Length at 154 days of age, $\mathrm{cm}$ & $47.19 \pm 0.63$ & $48.58 \pm 1.07$ \\
\hline Length gain $(\mathrm{B}-\mathrm{W}), \mathrm{cm} /$ day & $0.22 \pm 0.008$ & $0.25 \pm 0.013$ \\
\hline Length gain $(\mathrm{W}-154), \mathrm{cm} /$ day & $0.05 \pm 0.01$ & $0.04 \pm 0.01$ \\
\hline Length gain (B-154), cm/day & $0.13 \pm 0.00$ & $0.14 \pm 0.00$ \\
\hline Height at birth, cm & $38.81 \pm 0.34$ & $38.23 \pm 0.58$ \\
\hline Height at weaning, $\mathrm{cm}$ & $55.39 \pm 0.63$ & $54.50 \pm 1.07$ \\
\hline Height at 154 days of age, $\mathrm{cm}$ & $59.28 \pm 0.78$ & $58.80 \pm 1.34$ \\
\hline Height gain $(\mathrm{B}-\mathrm{W}), \mathrm{cm} /$ day & $0.23 \pm 0.01$ & $0.23 \pm 0.01$ \\
\hline Height gain (W-154), cm/day & $0.04 \pm 0.01$ & $0.05 \pm 0.01$ \\
\hline Height gain (B-154), cm/day & $0.13 \pm 0.00$ & $0.13 \pm 0.01$ \\
\hline
\end{tabular}

Table 4 - Linear regressions of the traits that were influenced by the weight of the dam at lambing (WDL)

\begin{tabular}{lcc}
\hline Linear regression equations & $\begin{array}{c}\text { Coefficient of } \\
\text { determination }\left(\mathrm{R}^{2}\right)\end{array}$ & $\begin{array}{c}\text { Standard } \\
\text { deviation }\end{array}$ \\
\hline WW $=3.0380+0.1982$ WDL & 0.80 & 2.73 \\
DAWGbw $=-0.0020+0.0027 \mathrm{WDL}$ & 0.76 & 0.04 \\
GW $=41.5651+0.2661 \mathrm{WDL}$ & 0.91 & 3.72 \\
DAGGbw $=0.0659+0.0036 \mathrm{WDL}$ & 0.98 & 0.05 \\
LB $=26.3581+0.0138 \mathrm{WDL}$ & 0.87 & 1.25 \\
LW $=35.9924+0.1467 \mathrm{WDL}$ & 0.88 & 2.71 \\
L154 $=42.1237+0.1096 \mathrm{WDL}$ & 0.71 & 2.50 \\
DALGbw $=0.1376+0.0019 \mathrm{WDL}$ & 0.82 & 0.04 \\
HW $=45.8412+0.1808 \mathrm{WDL}$ & 0.93 & 2.82 \\
H154 $=51.2754+0.1580 \mathrm{WDL}$ & 0.89 & 3.04 \\
DAHGbw $=0.1053+0.0023 \mathrm{WDL}$ & 0.64 & 0.03 \\
DALGw154 =0.0832 +0.0009WDL & 0.71 & 0.01 \\
\hline
\end{tabular}

WW - weight at weaning; DAWGbw - daily average weight gain from birth to weaning; GW - heart girth at weaning; DAGGbw - daily average heart girth gain from birth to weaning; LB - length at birth; LW - length at weaning; L154 - length at 154 days of age; DALGbw - daily average length gain from birth to weaning; HW - height at weaning; H154 - height at 154 days of age; DAHGbw - daily average height gain from birth to weaning; DALGw154 - daily average length gain from weaning to 154 days of age.

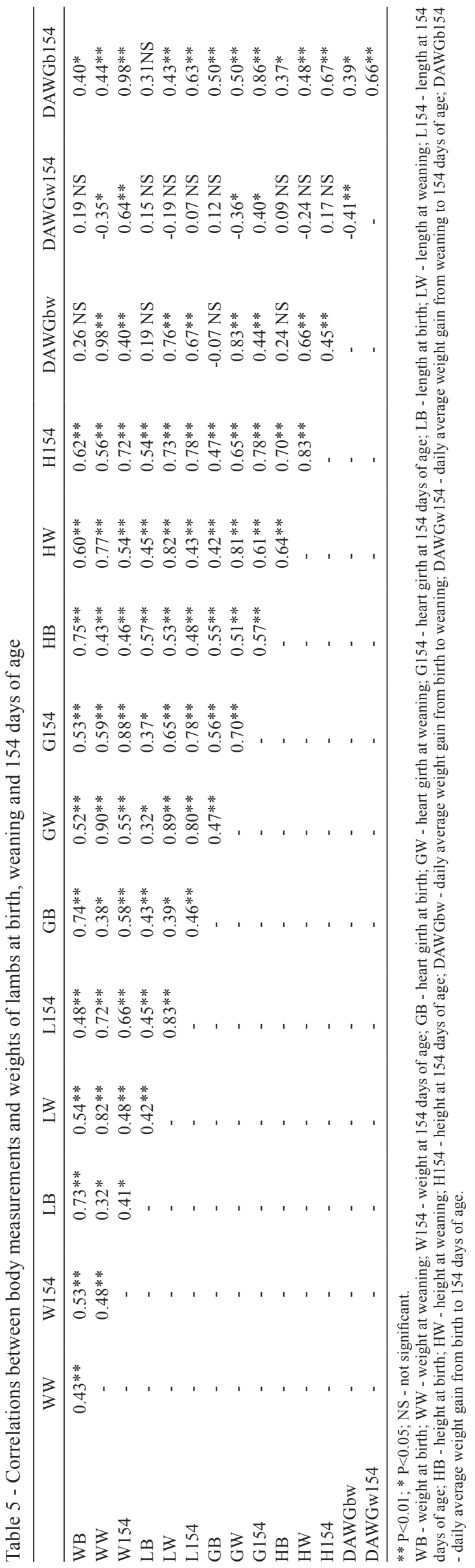

R. Bras. Zootec., v.42, n.2, p.87-94, 2013 
the body measurements can be used to predict the weight of the animals.

Simple and allometric linear regressions of Huxley (1932) were tested (Table 6) to predict live weight through body measurements. According to the coefficients of determination of the equations $\left(\mathrm{R}^{2}\right)$, the measurements at birth partly explain the weight at birth, but were not efficient to predict the weight at weaning, and the measurements at weaning explained weight at weaning.

The body measurement which presented the best coefficients of determination was heart girth. This result is in agreement with the ones found by Costa Júnior et al. (2006) and Reis et al. (2008). This was already expected because of the high correlations between this measure and weight.

Ewe farmers do not always have a scale at their property to evaluate animal performance. A viable alternative to avoid this problem is the use of regressions to estimate live weight through body measurements.

The linear equations presented results similar to those of the allometric equations for most of the traits (Table 6), disagreeing with the results described by Sowand \& Sobola (2008), who stated that the allometric equations are more efficient to predict the weight than the linear equations. However, these authors evaluated weights and measures of older animals, between 13 and 16 months of age, and of a different genetic group.
The multiple linear regressions presented better coefficients of determination than the simple ones (Table 7). This means that equations using more than one body measurement are more efficient to estimate the live weight than equations using only one measurement, which agrees with results obtained by Reis et al. (2008) and Sowand \& Sobola (2008).

Only the multiple equations with two measurements were presented, showing the highest coefficients of determination $\left(\mathrm{R}^{2}\right)$ for each age. In all of these, heart girth was present, confirming the importance of this measure in predicting the weight of the lambs. It was also observed that there was no major difference between the $\mathrm{R}^{2}$ of equations with two and three body measurements therefore regressions using only two measures were sufficient to predict the weight.

Nonlinear regression equations were determined from the body measurements to estimate the type of development of these measurements in relation to the weight (Table 8). According to Santos et al. (2001) the growth can be better evaluated through allometric equations, since they provide a quantitative description of the part/whole relationship.

Comparing the development of body measurements and weight gain (Figure 1), we can observe that the relationship between weight and height presented positive allometric growth $(\mathrm{P}<0.01)$, indicating that weight increased proportionally more than height in the studied period.

Table 6 - Parameters of linear and allometric regressions to estimate live weight of lambs at birth and weaning from body measurements

\begin{tabular}{|c|c|c|c|c|}
\hline Measurements & Intercept & Regression coefficient & Coefficient of determination $\left(\mathrm{R}^{2}\right)$ & Standard deviation \\
\hline \multicolumn{5}{|c|}{ Linear regression parameters to estimate live weight at birth } \\
\hline Heart girth at birth & -3.55793 & 0.19762 & 0.54 & 0.62 \\
\hline Length at birth & -4.06479 & 0.29375 & 0.52 & 0.62 \\
\hline Height at birth & -6.41792 & 0.26169 & 0.55 & 0.63 \\
\hline \multicolumn{5}{|c|}{ Linear regression parameters to estimate live weight at weaning } \\
\hline Heart girth at birth & -5.12498 & 0.51021 & 0.12 & 2.72 \\
\hline Heart girth at weaning & -23.33535 & 0.66363 & 0.81 & 3.43 \\
\hline Length at birth & -3.67231 & 0.65659 & 0.07 & 2.67 \\
\hline Length at weaning & -21.27054 & 0.80100 & 0.66 & 3.29 \\
\hline Height at birth & -16.39236 & 0.77406 & 0.17 & 2.77 \\
\hline Height at weaning & -27.25128 & 0.73952 & 0.59 & 3.21 \\
\hline Mensurements & Antilogarithm "a" & Regression coefficient & Coefficient of determination $\left(\mathrm{R}^{2}\right)$ & Standard deviation \\
\hline \multicolumn{5}{|c|}{ Allometric regression parameters to estimate live weight at birth } \\
\hline Heart girth at birth & 0.00666 & 1.75241 & 0.50 & 0.62 \\
\hline Length at birth & 0.00485 & 2.02352 & 0.54 & 0.60 \\
\hline Height at birth & 0.00033 & 2.54683 & 0.55 & 0.62 \\
\hline \multicolumn{5}{|c|}{ Allometric regression parameters to estimate live weight at weaning } \\
\hline Heart girth at birth & 0.10297 & 1.34720 & 0.10 & 2.71 \\
\hline Heart girth at weaning & 0.00023 & 2.73184 & 0.81 & 3.44 \\
\hline Length at birth & 0.25148 & 1.21138 & 0.06 & 2.66 \\
\hline Length at weaning & 0.00059 & 2.65624 & 0.67 & 3.40 \\
\hline Height at birth & 0.00941 & 1.98221 & 0.12 & 2.73 \\
\hline Height at weaning & 0.00005 & 3.09970 & 0.59 & 3.31 \\
\hline
\end{tabular}


Table 7 - Multiple linear regressions to estimate live weight at birth, weaning and 154 days of age from body measurements of lambs at birth, weaning and 154 days of age

\begin{tabular}{lcc}
\hline Prediction equations & Coefficient of determination $\left(\mathrm{R}^{2}\right)$ & Standard-deviation \\
\hline $\mathrm{WB}=-6.8307+0.1399 \mathrm{~GB}+0.2009 \mathrm{LB}$ & 0.76 & 0.66 \\
$\mathrm{WB}=-8.5534+0.1090 \mathrm{~GB}+0.1499 \mathrm{LB}+0.1083 \mathrm{HB}$ & 0.81 & 0.67 \\
$\mathrm{WW}=-18.8071+0.2662 \mathrm{~GB}+0.5804 \mathrm{HB}$ & 0.21 & 2.80 \\
$\mathrm{WW}=-19.7887+0.2492 \mathrm{~GB}+0.1485 \mathrm{LB}+0.5194 \mathrm{HB}$ & 0.22 & 2.81 \\
$\mathrm{WW}=-25.3749+0.6007 \mathrm{GW}+0.0998 \mathrm{HW}$ & 0.82 & 3.43 \\
$\mathrm{WW}=-25.3703+0.6067 \mathrm{GW}+-0.0117 \mathrm{LW}+0.1030 \mathrm{HW}$ & 0.82 & 3.43 \\
W154 $=-27.7970+0.8358 \mathrm{~GB}+0.4768 \mathrm{LB}$ & 0.37 & 3.66 \\
$\mathrm{~W} 154=-32.5831+0.7499 \mathrm{~GB}+0.3352 \mathrm{LB}+0.3008 \mathrm{HB}$ & 0.38 & 3.68 \\
$\mathrm{~W} 154=-18.4126+0.2837 \mathrm{GW}+0.3410 \mathrm{HW}$ & 0.33 & 3.61 \\
$\mathrm{~W} 154=-18.3013+0.4259 \mathrm{GW}+-0.2816 \mathrm{LW}+0.4180 \mathrm{HW}$ & 0.34 & 3.62 \\
$\mathrm{~W} 154=-29.3156+0.8591 \mathrm{G} 154+-0.1295 \mathrm{~L} 154$ & 0.79 & 4.18 \\
W154 $=-31.2026+0.8048 \mathrm{G} 154+-0.2094 \mathrm{~L} 154+0.1504 \mathrm{H} 154$ & 0.80 & 4.19
\end{tabular}

WB - weight at birth; WW - weight at weaning; W154 - weight at 154 days of age; GB - heart girth at birth; GW - heart girth at weaning; G154 - heart girth at 154 days of age; LB - length at birth; LW - length at weaning; L154 - length at 154 days of age; HB - height at birth; HW - height at weaning; H154 - height at 154 days of age.

Table 8 - Values of the antilog "a" (lna), coefficient of allometry (b), coefficient of determination ( $\mathrm{R}^{2}$ ) and type of growth of body measurements on weight in lambs from birth to 154 days of age

\begin{tabular}{lccccc}
\hline & No. & lna & $\mathrm{B}$ & $\mathrm{R}^{2}$ & Type of growth \\
\hline Length & 456 & -6.80558 & 2.47958 & 0.90 & Negative allometric** \\
Heart girth & 456 & -9.20378 & 2.92691 & 0.92 & Isometric** \\
Height & 456 & -10.5098 & 3.25833 & 0.88 & Positive allometric** \\
\hline
\end{tabular}

N0. - number of observations; ${ }^{* *} \mathrm{P}<0.01$.

However, the relationship between weight and body length presented negative allometric growth $(\mathrm{P}<0.01)$, indicating that length increased proportionally more than weight during the studied period. The weight and the heart girth of sheep presented an isometric relation $(b=2.92)$, indicating that the growth rates of weight and heart girth were similar from birth to 154 days of age, which might explain the higher correlation between the weight and this trait (Table 8).

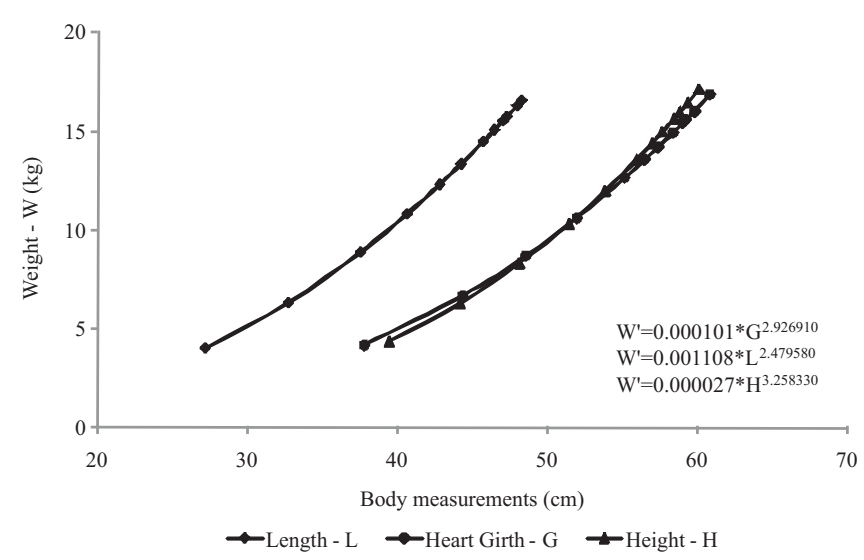

Figure 1- Weight gain in relation to body measurements of lambs from birth to 154 days of age.

\section{Conclusions}

It is important to consider the various environmental factors in sheep production, since they affect lamb performance, especially the type of birth, which affects most of the birth traits at 154 days of age. It is possible to efficiently predict the weight from the body morphometry through regression in the absence of a scale. The body measurement that best explains weight is heart girth because of their high correlations and similar growth rates.

\section{References}

ARAÚJO FILHO, J.T.; COSTA, R.G.; FRAGA, A.B. et al. Efeito de dieta e genótipo sobre medidas morfométricas e não constituintes da carcaça de cordeiros deslanados terminados em confinamento. Revista Brasileira de Saúde e Produção Animal, v.8, n.4, p.394-404, 2007.

BARROS, N.N.; VASCONCELOS, V.R.; WANDER, A.E. et al. Eficiência bioeconômica de cordeiros F1 Dorper x Santa Inês para produção de carne. Pesquisa Agropecuária Brasileira, v.40, n.8, p.825-831, 2005.

CARNEIRO, P.L.S.; MALHADO, C.H.M.; SOUZA JUNIOR, A.A.O. et al. Desenvolvimento ponderal e diversidade fenotípica entre cruzamentos de ovinos Dorper com raças locais. Pesquisa Agropecuária Brasileira, v.42, n.7, p.991-998, 2007.

COSTA JÚNIOR, G.S.; CAMPELO, J.E.G.; AZEVEDO, D.M.M.R. et al. Caracterização morfométrica de ovinos da raça Santa Inês criados nas microrregiões de Teresina e Campo Maior, Piauí. Revista Brasileira de Zootecnia, v.35, n.6, p.2260-2267, 2006. 
FAJEMILEHIN, O.K.S.; SALAKO, A.E. Body measurement characteristics of the West African Dwarf (WAD) Goat in deciduous forest zone of Southwestern Nigeria. African Journal of Biotechnology, v.7, p.2521-2526, 2008.

FERNANDES,A.A.O.; BUCHANAN, D.; SELAIVE-VILLARROEL, A.B. Avaliação dos fatores ambientais no desenvolvimento corporal de cordeiros deslanados da raça Morada Nova. Revista Brasileira de Zootecnia, v.30, n.5, p.1460-1465, 2001.

HUXLEY, J.S. Problems of relative growth. London: Methuen, 1932. 276p

KORITIAKI, N.A.; RIBEIRO, E.L.A.; SCERBO, D.C. et al. Fatores que afetam $\mathrm{O}$ desempenho de cordeiros Santa Inês puros e cruzados do nascimento ao desmame. Revista Brasileira de Saúde e Produção Animal, v.13, n.1, p.258-270, 2012.

MENEZES, L.F.G.; RESTLE, J.; KUSS, F. et al. Medidas corporais de novilhos das gerações avançadas do cruzamento rotativo entre as raças Charolês e Nelore, terminados em confinamento. Ciência Rural, v.38, n.3, p.771-777, 2008.

MEXIA, A.A.; MACEDO, F.A.F.; ALCADE, C.R. et al. Desempenhos reprodutivo e produtivos de ovelhas Santa Inês suplementadas em diferentes fases da gestação. Revista Brasileira de Zootecnia, v.33, n.3, p.658-667, 2004.

MOHAMMADI, K.; BEYGI NASSIRI, M.T.; FAYAZI, J. et al. Investigation of environmental factors influence on pre-weaning growth traits in Zandi lambs. Journal of Animal and Veterinary Advances, v.9, n.6, p.1011-1014, 2010.

MOURA FILHO, J.; RIBEIRO, E.L.A.; SILVA, L.D.F. et al. Suplementação alimentar de ovelhas no terço final da gestação: desempenho de ovelhas e cordeiros até o desmame. Semina: Ciências Agrárias, v.26, n.2, p.257-266, 2005.

NUNES, M.T. Crescimento e desenvolvimento. In: AIRES, M.M. (Ed.) Fisiologia. 3.ed. Rio de Janeiro: Guanabara Koogan, 2008. p.1097-1104.

PACHECO, A.; QUIRINO, C.R. Estudo das características de crescimento em ovinos. Pubvet, v.2, n.29, p.1982-1263, 2008.
PEREZ, J.R.O. Ovinocultura: aspectos produtivos. Lavras: GAO, 2002. 178p.

RASHIDI, A.; MOKHTARI, M.S.; JAHANSHAHI, A.S. et al. Genetic parameter estimates of pre-weaning growth traits in Kermani ewe. Small Ruminant Research, v.74, p.165-171, 2008.

REIS, L.R.; ALBIQUERQUE, F.H.M.A.R.; VALENTE, B.D. et al. Predição do peso vivo a partir de medidas corporais em animais mestiços Holandês/Gir. Ciência Rural, v.38, n.3, p.778-783, 2008.

ROCHA, L.P.; FRAGAA.B.; ARAÚJO FILHO J.T. et al. Desempenho de cordeiros cruzados em Alagoas, Brasil. Archivos de Zootecnia, v.58, n.221, p.145-148, 2009.

ROCHA, M.A.; RIBEIRO; E.L.A.; MIZUBUTI; I.Y. et al. Parâmetros de crescimento e suas correlações em idades entre 60 as 240 dias na carpa húngara (Cyprinos carpio). Semina: Ciências Agrárias, v.23, n.1, p.29-34, 2002.

SANTOS, C.L.; PÉREZ, J.R.O.; MUNIZ, J.A. et al. Desenvolvimento relativo dos tecidos ósseo, muscular e adiposo dos cortes da carcaça de cordeiros Santa Inês. Revista Brasileira de Zootecnia, v.30, n.2, p.487-492, 2001.

SILVA, D.C.; AZEVÊDO, D.M.M.; ALVES, A.A. et al. Estimativa do peso vivo através do perímetro torácico de ovinos Santa Inês. Revista Ciência e Produção Animal, v.8, n.2, p.41-46, 2006.

SILVA, F.L.R.; ARAÚJO, A.M. Características de Reprodução e de Crescimento de ovinos mestiços Santa Inês, no Ceará. Revista Brasileira de Zootecnia, v.29, n.6, p.1712-1720, 2000.

SOUZA, J.E.R.; MARTINS FILHO, R.; OLIVEIRA, S.M.P. et al. Influência dos fatores de ambiente no desempenho ponderal de bovinos da raça Nelore no Estado do Ceará. Revista Ciência Agronômica, v.34, n.2, p.133-138, 2003.

SOWAND, O.S.; SOBOLA, O.S. Body measurements of West African Dwarf sheep as parameters for estimation of live weight. Tropical Animal Health and Production, v.40, p.433-439, 2008. 